\title{
Effect of Anion and Amino Functional Group on Resin for Lipase Immobilization with Adsorption-Cross Linking Method
}

\author{
Andi Nuraliyah, Annisa Kurnia, Ibnu Maulana, Anondho Wijanarko, and Heri Hermansyah
}

\begin{abstract}
Lipase is one of biocatalysts which have been used commercially for processes in industries, such as bioenergy, food, and pharmaceutical industry. Nowadays, biocatalysts are preferred in industries because they work in mild condition, have high specificity, and reduce energy consumption (high pressure and temperature). But, the usage of lipase for industrial scale is limited by economic reason due to expensive price of lipase and difficulty of separation system. Immobilization of lipase is one of the solution to maintain activity of lipase and reduce separation system in process. Therefore, we conduct study about lipase immobilization with adsorption-cross linking method using glutaraldehyde because this method produce high enzyme loading and stability. Lipase is immobilized on different kind of resin with various functional group. Highest enzyme loading (76.69\%) was achieved by lipase immobilized on anion macroporous resin which have anion functional group $\left(\mathrm{OH}^{-}\right)$. However, highest activity $(24,69 \mathrm{U} / \mathrm{g}$ support) through olive oil emulsion method was achived by lipase immobilized on anion macroporous-chitosan which have amino $\left(\mathrm{NH}_{2}\right)$ and anion $\left(\mathrm{OH}^{-}\right)$functional group. In addition, it also successed to produce biodiesel with yield reaching $50,6 \%$ through interesterification reaction and after 4 cycles it still produced a yield of $63.9 \%$ relative to initial yield. Meanwhile, for Aspergillus niger lipase immobilized on anion macroporous chitosan is show unit activity of $22,84 \mathrm{U} / \mathrm{g}$ resin and biodiesel yield higher than commercial lipase $(69,1 \%)$ and after 4 cycles it is still stable reach $\mathbf{7 0 . 6 \%}$ relative from initial yield. This shows that optimum functional group on support for immobilization with adsorption-cross linking is support that contains amino $\left(\mathrm{NH}_{2}\right)$ and anion $\left(\mathrm{OH}^{-}\right)$functional groups because they can react with glutaraldehyde and bind with enzyme, therefore preventing the desorption of lipase from support through binding lipase with functional group on support.
\end{abstract}

Index Terms-Adsorption-cross linking, lipase, resin, immobilization.

\section{INTRODUCTION}

Enzyme is a promising biocatalyst for organic reaction which have been applied commercially for proceses in industries, such as food, detergent, bioenergy, and pharmaceutical industries [1]. Based on Wang et al. [2] the demand of enzymes is increasing every year especially for biofuel production.

Biodiesel is one of biofuels that has attracted the attention from all over the world in recent years because biodegradability and eco-friendly nature. The conventional

Manuscript received May 30, 2016; revised December 17, 2016.

A. Nuraliyah, A. Kurnia, I. Maulana, A. WIjanarko and H. Hermansyah are with Chemical Engineering Department, Faculty of Engineering, Universitas Indonesia, Depok 16424 Indonesia (e-mail: heri@che.ui.ac.id). biodiesel technology is usually catalyzed by inorganic base or acid, which makes the separation of catalyst from products have certain drawbacks such as more complex process and higher energy consumption,-therefore consequently increases the cost of production [1], [2]. Lipase is an important enzyme that can be used not only for biodiesel production but also in reactions such as hydrolysis, esterification, transesterification, and interesterification. Biodiesel production starts to utilize biocatalyst because their ability to work in mild condition, have higher specificity, and reduces energy consumption for process (high pressure and temperature) than chemical catalyst (acid and base) [3]. But, the usage of lipase for industrial scale is limited by economic reason due to the expensive price of lipase and difficulty of separation system.

Immobilization of lipase is one of the solution to maintain activity of lipase and reduce separation system in process. Characteristics of support and immobilization methods are two important key in enzyme immobilization. One of the support that can be used for the immobilization of enzymes is resin. Resin is a synthetic organic support a wider surface than inorganic (metal) support because in general the resin has the pores so that it can adsorbed better than the inorganic support.

One of immobilization methods is adsorption-cross linking between support and enzyme. Cross linking between lipase and support will maintain the activity and stability of enzyme during reaction. Enzyme immobilization on resin with adsorption- cross linking method has been done on mesoporous resin [2]. Previous studies show that lipase immobilization on NW-ZT2 with adsorption-cross linking method gives high enzyme loading and high stabillity [4]. Because of that, this research will use resins with various functional groups as a support on immobilization by adsorption-cross linking method with glutaraldehyde as cross-linker. Anion and Amino functional group are focused in this research. Objectives of this research are to determine the best support for immobilization with adsorption-cross linking method and the best support will be used for immobilization of A.niger lipase.

\section{MATERIALS AND METHODS}

\section{A. Materials}

Candida rugosa Lipase, macroporous resin Amberlite, and anion macroporous resin Lewatit MP-64 was purchased from Sigma Aldrich. Aspergillus niger Lipase was produced independently with Aspergillus niger strain from LIPI. Chitosan, acetic acid, $\mathrm{KH}_{2} \mathrm{PO}_{4}, \quad \mathrm{~K}_{2} \mathrm{HPO}_{4} \cdot 3 \mathrm{H}_{2} \mathrm{O}$, and 
glutaraldehyde as other immobilization materials. Olive oil, distilled water, and PVA for unit activity testing. Palm oil and methyl acetate for biodiesel synthesis

\section{B. Preparation of Amino Functional Group on Resin}

Resin with amino functional group was prepared according to the methodology described by Kai Liu [5] with slight modification. Chitosan solution was prepared by adding $0.2 \mathrm{~g}$ chitosan into $25 \mathrm{ml} 5 \% \mathrm{v} / \mathrm{v}$ acetic acid. Then $2 \mathrm{~g}$ of macroporous resin was added and shaked in water bath 150 $\mathrm{rpm}, 30^{\circ} \mathrm{C}$ for $8 \mathrm{~h}$. Macroporous-chitosan resin was then filtered by filter paper and stored in $4^{\circ} \mathrm{C}$. Anion-Chitosan resin was obtained from same method by replacing macroporous resin with anion resin.

\section{Production of Dry Extract (Powder) Aspergillus niger Lipase}

Aspergillus niger lipase was produced by fermentation solid state for 5 days using rice bran medium and $2 \%$ olive oil inducer. Then, the result of fermentation was extracted by mixing, filtration, and centrifugation. Skim milk powder $(12 \%)$ was added in to the supernantant and then dried using spray dryer.

\section{Immobilization of Lipase with Adsorption-Cross Linking}

0,1 g of Candida rugosa Lipase and Aspergillus niger lipase powder was dissolved in $10 \mathrm{ml}$ phospate buffer solution (PBS $\mathrm{pH} \mathrm{7,0.1} \mathrm{M)} \mathrm{and} \mathrm{stirred} \mathrm{until} \mathrm{it} \mathrm{is} \mathrm{fully.} \mathrm{Lipase}$ adsorption was done in shaking water bath with operating condition of $30^{\circ} \mathrm{C}$ and $150 \mathrm{rpm}$ for 4 hours. Then, $0.5 \%$ glutaraldehyde solution was added to the system and reacted for $20 \mathrm{~min}$. The immobilized lipase was then separated and stored at $4^{\circ} \mathrm{C}$ until usage.

\section{E. Enzyme Loading Assay}

Enzyme concentrations were determined by the Lowry method using bovine serum albumin as the standard. Then, the sample was analyzed by UV-Vis spectrophotometer at $750 \mathrm{~nm}$. Absorbance of spectrophotometer will be used for calculate enzyme concentration using standard equation. Enzyme loading was calculated by :

$$
\mathrm{X}_{\mathrm{L}}=\left(\mathrm{C}_{0}-\mathrm{C}_{\mathrm{t}} / \mathrm{C}_{0}\right) \times 100 \%
$$

\section{F. Measurement of Lipase Unit Activity}

The activity of lipase was assayed by titrating the fatty acid produced in the hydrolysis of olive oil. Olive oil emulsion was prepared by dissolving $0.3 \mathrm{~g}$ PVA in $5 \mathrm{ml}$ water, and adding 5 $\mathrm{ml}$ olive oil and stirred until fully dissolved. Olive oil emulsion and $4 \%$ lipase immobilized was reacted at $40^{\circ} \mathrm{C}$ for $30 \mathrm{~min}$ for hydrolysis and ethanol was added to terminate the reaction [SNI]. The produced fatty acid was titrated using $0.05 \mathrm{M} \mathrm{NaOH}$. One unit of activity was defined as the amount of enzyme required to release $1 \mu \mathrm{mol}$ of free fatty acid per min under the assay conditions.

\section{G. Enzymatic Production of Biodiesel}

Biodiesel synthesis was carried out by interesterification reaction. Palm oil and methyl acetate was added into the 100 $\mathrm{ml}$ erlenmeyer with molar ratio 1:12. Then, $0.25 \mathrm{~g}$ of immobilized lipase was added into the system. The reaction were conducted at $40^{\circ} \mathrm{C}$, batch system, and sampling after 50 h [6]. Methyl ester (biodiesel) concentration was analyzed by HPLC instrument.

\section{RESULTS AND DISCUSSIONS}

\section{A. Result of Lipase Immobilization with Adsorption Cross Linking Method}

Lipase which was used in this step is Candida rugosa lipase. Objective of this step is to determine the best support for immobilization with adsorption-cross linking method. Results of lipase immobilization with adsorption-cross linking (Table I) were evaluated through enzyme loading, unit activity, and biodiesel synthesis.

\section{1) Effect of functional group on enzyme loading}

Enzyme loading of lipase on all resin are shown in Fig. 1. All enzyme loading after cross linking increased from enzyme loading after adsorption. This shows that the amount of lipase adsorbed on resin increased after the addition of glutaraldehyde.

TABLE I : SUMMARY OF CANDIDA RUGOSA LIPASE IMMOBILIZATION RESULT WITH ADSORPTION-CROSS LINKING METHOD

\begin{tabular}{|c|c|c|c|c|c|c|}
\hline Code & Resin & Porosity & Chitosan Addition & Functional Group & $\begin{array}{c}\text { \% Enzyme Loading } \\
\text { (Adsorpsi ; Cross Linking) }\end{array}$ & $\begin{array}{c}\text { Unit Activity } \\
\text { (U/g resin) }\end{array}$ \\
\hline $\mathrm{M}$ & \multirow{2}{*}{ Macroporous } & Yes & Without Chitosan & None & $(49.25 ; 63.56)$ & 15.1 \\
\hline MK & & Yes & With Chitosan & Amino $\left(-\mathrm{NH}_{2}\right)$ & $(62.88 ; 70.00)$ & 18.2 \\
\hline $\mathrm{AG}$ & \multirow[b]{2}{*}{ Anion Gelular } & No & Without Chitosan & Anion $\left(\mathrm{OH}^{-}\right)$ & $(30.69 ; 50.18)$ & 15.3 \\
\hline AGK & & No & With Chitosan & $\begin{array}{c}\text { Anion }\left(\mathrm{OH}^{-}\right) \\
\text {Amino }\left(-\mathrm{NH}_{2}\right)\end{array}$ & $(32.72 ; 41.63)$ & 15.7 \\
\hline $\mathrm{AM}$ & \multirow[b]{2}{*}{ Anion Macroporous } & Yes & Without Chitosan & Anion $\left(\mathrm{OH}^{-}\right)$ & $(31.75 ; 75.60)$ & 20.4 \\
\hline AMK & & Yes & With Chitosan & $\begin{array}{c}\text { Anion }\left(\mathrm{OH}^{-}\right) \\
\text {Amino }\left(-\mathrm{NH}_{2}\right)\end{array}$ & $(35.83 ; 57.24)$ & 24.7 \\
\hline
\end{tabular}

Enzyme loading after adsorption of lipase on resin with chitosan (MK, AGK, AMK) is higher than enzyme loading after adsorption without chitosan (M, AG, AM). This happened because the amino group on resin surface participated in making a hydropillic support, where hydrophillic site of other amino group from lipase will be adsorbed and form hydrogen bonding and therefore helps increasing lipase adsorption [7]-[9].

Enzyme loading difference between cross linking and adsorption on anion resin is higher than macroporous resin because the anion $\left(\mathrm{OH}^{-}\right)$group on resin is able to react with glutaraldehyde and bind more lipase to the resin. But, the 
enzyme loading difference on resin with chitosan (MK, AGK, and $\mathrm{AMK})$ which contains amino $\left(\mathrm{NH}_{2}\right)$ group is lower than anion resin without chitosan [10]. This happened because the amino group from chitosan might have leached off into the system and was detected as protein at enzyme loading measurement.

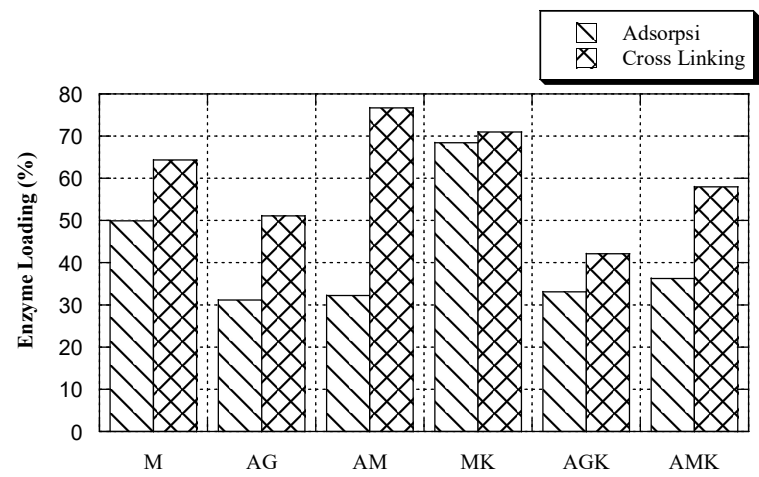

Fig. 1. Enzyme Loading Immobilization of Candida rugosa Lipase with Adsorption-Cross Linking.

\section{2) Effect of functional group on unit activity}

Lipase unit activity $(\mathrm{U})$ is defined as lipase ability to release $1 \mu \mathrm{mol}$ of free fatty acid per minute under $40^{\circ} \mathrm{C}$. Activity assay of lipase immobilized on resin with various functional groups is shown in Fig. 2. Unit activity of lipase immobilized on resin-with anion groups are (15.3 and $20.4 \mathrm{U} / \mathrm{g}$ resin) higher than lipase immobilized on macroporous resin which doesn't have functional group (15.1 U/g resin). This happened because on anion resin, glutaraldehyde reacts with anion group $\left(\mathrm{OH}^{-}\right)$, and the reaction between glutaraldehyde and the adsorbed lipase which contain amino group is reduced therefore preventing breakage of the catalytic site of lipase. On the contrary, in macroporous resin which contains amino group, glutaraldehyde will attack the adsorbed lipase and causes damage in the lipase's catalytic site. Finally, the activity unit of lipase immobilized on anionic resin is higher than macroporous resin.

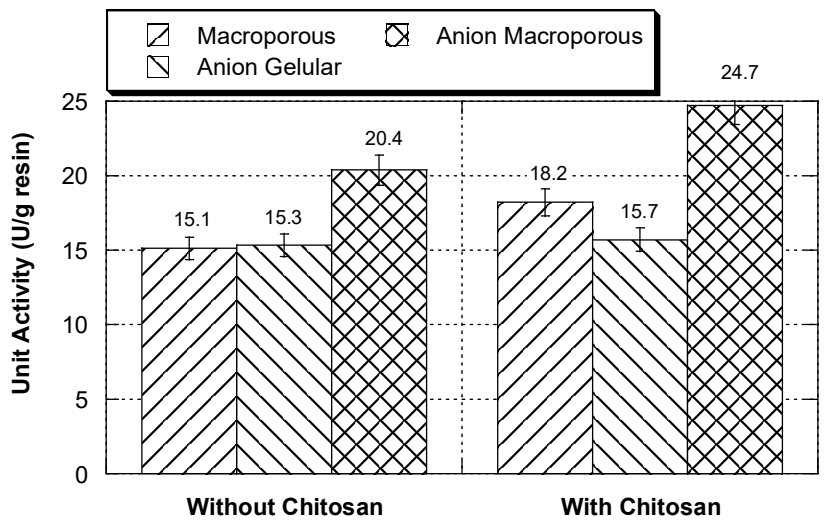

Fig. 2. Unit Activity of Candida rugosa Lipase Immobilized with Adsorption-Cross Linking.

Activity unit of lipase immobilized on anion macroporous (20.4 U/g resin) is higher than that of lipase immobilized on macroporous resin with chitosan $(18.2 \mathrm{U} / \mathrm{g}$ resin) which have amino group $\left(\mathrm{NH}_{2}\right)$ on the resin's surface. This happened because enzyme loading on anionic resin is higher than resin with amino group from chitosan because the amino group might leach from the resin's surface. If glutaraldehyde reacts with the anion group, the catalytic site of lipase will not be damaged and as consequences activity of lipase immobilized on anion macroporous resin is higher than lipase immobilized on macroporous resin with chitosan.

The activity of lipase immobilized on resin with chitosan (MK, AGK, AMK) are higher than those of lipase immobilized on resin without chitosan (M, AG, AM). This happened because lipase was adsorbed on a support that contains amino group through hydrophillic site, so it will be easier for the hydrophobic site which is the catalytic site of lipase to reach its substrate oil which is also hydrophobic. In addition, there are many functional groups on anion macroporous resin with chitosan which have anion and amino groups, so there are more lipase binded with anion and amino group of support. Therefore, the activity of lipase immobilized on resin with chitosan is higher than lipase immobilized on resin without chitosan. Highest activity was obtained by lipase immobilized on anion resin with chitosan because The existence of anion and amino groups on the support prevents glutaraldehyde from attacking the catalytic site of lipase.

\section{3) Effect of functional group on biodiesel yield and stability}

Only two immobilized lipase that were used for biodiesel synthesis, they are lipase immobilized on anion macroporous resin (AM) and lipase immobilized on anion macroporous with chitosan (AMK). These immobilized lipase were used because they showed higher unit activity than the other immobilized lipase. The activity of both lipase were then tested by biodiesel synthesis and we will compare the hydrolitic and interesterification activity of immobilized lipase. The result of biodiesel yield from lipase immobilized on AM and AMK are shown in Fig. 3.

Lipase immobilized on anionic macroporous resin with chitosan AMK was able to produce biodiesel yield (50.6\%) higher than lipase immobilized on anion macroporous resin AM (27.2\%). Activity of lipase catalizing interesterification reaction is proportional with the hydrolitic activity. This shows that catalysis activity of lipase immobilized on anion macroporous resin with chitosan is better than lipase immobilized on anion macroporous resin without chitosan. The lipase immobilized on anion macroporous resin with chitosan were reused in 4 cycles of biodiesel synthesis to test the stabillity of immobilized lipase. Biodiesel yield in every cycle is shown in Fig. 4.

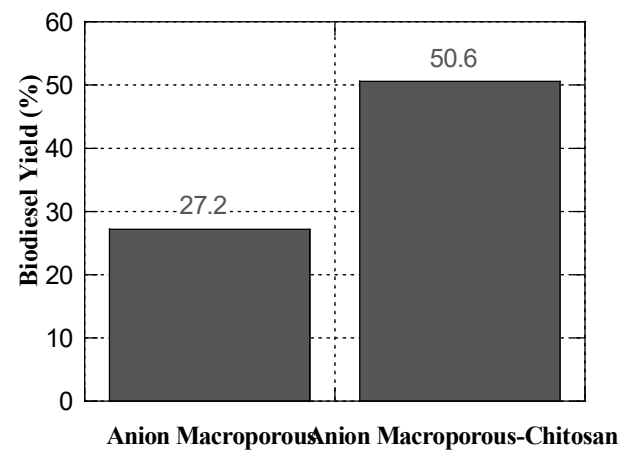

Fig. 3. Biodiesel Yield of Candida rugosa Lipase Immobilized with Adsorption-Cross Linking. 


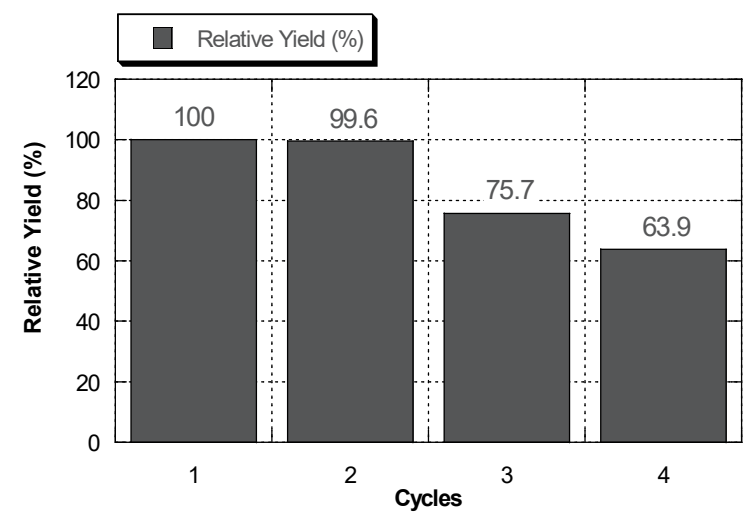

Fig. 4. Stabillity of Candida rugosa Lipase Immobilized with Adsorption-Cross Linking.

After $2^{\text {nd }}$ cycle of biodiesel synthesis, lipase immobilized on anion macroporous with chitosan is still stable with biodiesel yield reaching $99.6 \%$ relative to the initial yield. Then, after $3^{\text {rd }}$ and $4^{\text {th }}$ cycles, biodiesel yield decreased to $75.7 \%$ and $63.9 \%$ relative from initial yield. This shows that after four reaction cycles, lipase immobilized on anion macroporous resin with chitosan is able to maintain the activity to catalyze interesterification reaction with biodiesel tield of $63.9 \%$ relative to the initial yield (from $50.6 \%$ become $32.4 \%$ ). However, it is predicted that the biodiesel yield will continue to decline after 5 th cycles and so on.

\section{B. Immobilization of Aspergillus niger Lipase with Adsorption-Cross Linking}

The dry extract of Aspergillus niger Lipase that we produced have unit activity of $55.83 \mathrm{U} / \mathrm{g}$ lipase, which is higher than that of crude extract / supernatant of Aspergillus niger Lipase $13.82 \mathrm{U} / \mathrm{ml}$. This happens because the dry extract is more pure than the crude extract that had high water contents [11]. Then, this lipase was immobilized on the best support (anion macroporous resin with chitosan). Result of immobilized dry extract of Aspergillus niger lipase with adsorption-cross Linkin was also evaluated through enzyme loading, unit activity, and usage in biodiesel synthesis. Then, we compared the result with immobilization result of Candida rugosa lipase in Table II.

TABLE II: COMPARISON IMMOBILIZED CANDIDA RUGOSA LIPASE AND ASPERGILLUS NIGER LIPASE ON ANION MACROPOROUS RESIN WITH CHITOSAN (ADSORPTION-CROSS LINKING METHOD)

\begin{tabular}{|c|c|c|c|}
\hline & & $\begin{array}{c}\text { Immobilized } \\
\text { Candida rugosa } \\
\text { Lipase }\end{array}$ & $\begin{array}{c}\text { Immobilized } \\
\text { Aspergillus niger } \\
\text { Lipase } \\
\end{array}$ \\
\hline \multirow[t]{2}{*}{1} & Enzyme Loading & & \\
\hline & $\begin{array}{l}\text { - Adsorption } \\
\text { - Cross Linking }\end{array}$ & $\begin{array}{l}35.83 \% \\
57.24 \%\end{array}$ & $\begin{array}{l}35.12 \% \\
48.86 \%\end{array}$ \\
\hline \multirow[t]{2}{*}{2} & Unit Activity & & \\
\hline & $\begin{array}{l}\text { - Free } \\
\text { - Immobilized }\end{array}$ & $\begin{array}{l}702.2 \mathrm{U} / \mathrm{g} \text { lipase } \\
24.69 \mathrm{U} / \mathrm{g} \text { resin }\end{array}$ & $\begin{array}{l}55.83 \mathrm{U} / \mathrm{g} \text { lipase } \\
22.84 \mathrm{U} / \mathrm{g} \text { resin }\end{array}$ \\
\hline 3 & Biodiesel Yield & $50.6 \%$ & $69.1 \%$ \\
\hline
\end{tabular}

Enzyme loading of Aspergillus niger lipase is almost the same like Candida rugosa Lipase (Commercial), altough the total enzyme loading of Aspergillus niger lipase was lower than Candida rugosa Lipase. In addition, the unit activity of immobilized Aspergillus niger lipase is also at a similar value with immobilized Candida rugosa lipase despite the free lipase activity showing high differences $(55.83 \mathrm{U} / \mathrm{g}$ lipase and
$702.22 \mathrm{U} / \mathrm{g}$ lipase respectively). This happens because catalytic efficiency of Aspergillus niger lipase is higher than Candida rugosa lipase (Table III). Catalytic efficiency, defined as the ratio between activity and loading, gives the hint of the adaptation level of the immobilized lipase. The higher the ratio the lower the amount of lipase inactivated by the immobilization process [12]. Therefore, altough unit activity of free lipase have high difference, it is possible that the activity of immobilized Aspergillus niger lipase is almost the same with immobilized Candida rugosa lipase because of their catalytic efficiency difference.

TABLE III: CATALYTIC EFFICIENCY

\begin{tabular}{lcc}
\hline \hline & Salis, 2008 & $\begin{array}{c}\text { This Experiment, } \\
\mathbf{2 0 1 5}\end{array}$ \\
\hline Immobilization & Adsorption & $\begin{array}{c}\text { Adsorption-Cross } \\
\text { Linking }\end{array}$ \\
Catalytic Efficiency & & \\
- Candida rugosa Lipase & 0.045 & 0.035 \\
- Aspergillus niger lipase & 0.370 & 0.410 \\
\hline \hline
\end{tabular}

Biodiesel yield of immobilized Aspergillus niger lipase is higher than immobilized Candida rugosa lipase. This shows that Aspergillus niger lipase is more active on interesterification reaction than hydrolysis reaction. In addition, immobilized Aspergillus niger lipase is more stable than immobilized Candida rugosa lipase because after $4^{\text {th }}$ reaction cycle it maintained $70.6 \%$ of its initial activity. The stabillity of immobilized Aspergillus niger lipase is compared with immobilized Candida rugosa lipase and is shown in Fig. 5. This shows that enzyme immobilization of lipase with adsorption-cross linking method was able to prevent desorption of lipase from support because of the bond created between lipase and functional groups on support, and therefore the enzymatic activity stability of immobilized lipase can be maintained.

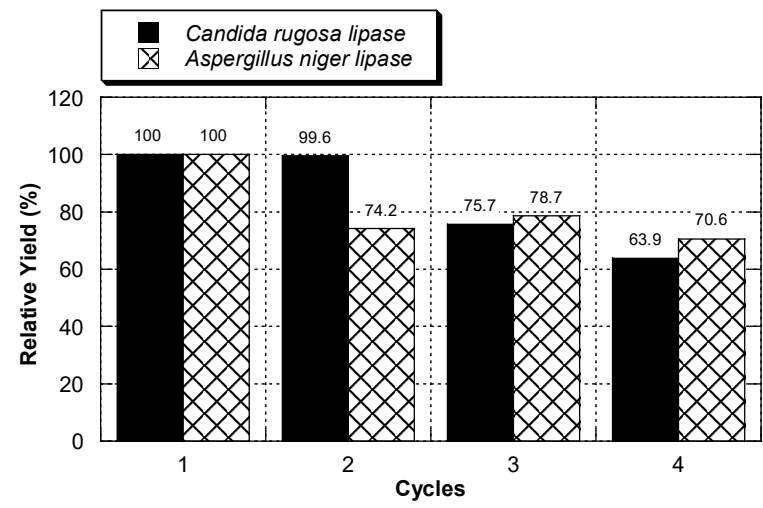

Fig. 5. Comparison Stabillity of Immobilized Aspergillus niger lipase and Candida rugosa Lipase with Adsorption-Cross Linking Method.

\section{CONCLUSION}

The presence of anion and amino groups on support gives a good effect on immobilization of lipase with adsorption-cross linking method. Lipase immobilized on anion macroporous with chitosan which contains amino $\left(\mathrm{NH}_{2}\right)$ and anion $(\mathrm{OH}-)$ groups has the highest unit activity ( $24.7 \mathrm{U} / \mathrm{g}$ resin), biodiesel yield $(50.6 \%)$, and after $4^{\text {th }}$ reaction cycle it was able to maintain $63.9 \%$ of its initial activity because glutaraldehyde 
reacts with the anion and amino groups on support and prevents damage in catalytic site of lipase. In addition, Aspergillus niger lipase is more active (69.1\%) and stable on interesterification reaction (after 4 reaction cycles it was able to maintain $70.6 \%$ of its initial activity) than hydrolysis reaction. This shows that immobilization of lipase with adsorption-cross linking method prevented desorption of lipase from support through binding lipase with functional groups on support.

\section{ACKNOWLEDGMENT}

This work was supported by grants from DP2M, Direktorat Jenderal Pendidikan Tinggi Indonesia (DIKTI) and Direktorat Riset dan Pengabdian Masyarakat (DRPM) Universitas Indonesia.

\section{REFERENCES}

[1] Y. D. Wang et al., "Immobilized recombinant Rhizopus oryzae lipase for the production of biodiesel in solvent free system," Journal of Molecular Catalysis B: Enzymatic, vol. 67, pp. 45-51, July 2010.

[2] W. Q. Wang, Y. J. Jiang, L. Zhou, and J. Gao, "Comparison of the properties of lipase immobilized onto mesoporous resins by different methods," Appl Biochem Biotechnol, vol. 164, pp. 561-572, Jan. 2011.

[3] Y. Q. Xu, G.-W. Zhou, C. Wu, T.-H. Li, and H. Song, "Improving adsorption and activation of the lipase immobilized in amino-functionalized ordered mesoporous SBA-15," Solid State Sciences, vol. 13, pp. 867-874, March 2011.

[4] J. J. Yang et al., "Lipase immobilized by modification-coupled and adsorption-cross-linking methods: A comparative study," Biotechnology Advances, vol. 28, pp. 644-650, May 2010.

[5] K. Liu, G. Zhao, B. He, L. Chen, and L. Huang, "Immobilization of pectinase and lipase on macroporous resin coated with chitosan for treatment of whitewater from papermaking," Bioresource Technology, vol. 123, pp. 616-619, August 2012.

[6] H. Hermansyah and S. Marno, "Interesterification palm oil with methyl acetate using biocatalyst for biodiesel production," Depok, Indonesia: Universitas Indonesia, 2008.

[7] Y. J. Yan, X. Y. Zhang, and D. Chen, "Enhanced catalysis of Yarrowia lipolytica lipase LIP2 immobilized on macroporous resin and its application in enrichment of polyunsaturated fatty acids," Bioresource Technology, vol. 131, pp. 179-187, 2013.

[8] T. Liu et al., "Improving catalytic performance of Burkholderia cepacia lipase immobilized on macroporous resin NKA," Journal of Molecular Catalysis B: Enzymatic, vol. 71, no. 1, pp. 45-50, 2011.

[9] W. Bai et al., "Immobilization of lipase on aminopropyl-grafted mesoporous silica nanotubes for the resolution of (R, S)-1-phenylethanol," Journal of Molecular Catalysis B: Enzymatic, Nov. 2011.

[10] K. Liu et al., "Immobilization of pectinase and lipase on macroporous resin coated with chitosan for treatment of whitewater from papermaking," Bioresource Technology, vol. 123, pp. 616-619, 2012

[11] H. Hermansyah and I. Hariyani, "Production dry extract extracellular lipase from fungus Aspergillus niger by solid state fermentation method," Depok, Indonesia: Universitas Indonesia, 2014.

[12] A. Salis et al., "Comparison among immobilised lipases on macroporous polypropylene toward biodiesel synthesis," Journal of Molecular Catalysis B: Enzymatic, vol. 54, pp. 9-26, March 2008.

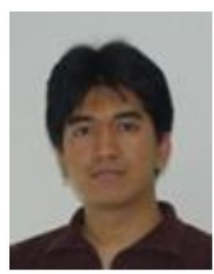

Heri Hermansyah was born at Sukabumi on January 18,1976 . He received his bachelor's degree in gas and petrochemical engineering from Universitas Indonesia, Depok, Indonesia in 1998, the M.Eng and $\mathrm{PhD}$ degrees in chemical engineering fromTohoku University, Sendai, Japan in 2003 and 2006, respectively.

He is now an associate dean for Student Association and Ventura for Faculty of Engineering, Universitas Indonesia, Depok 16424, Indonesia. He started his academic career as a lecturer in chemical engineering at Universitas Indonesia. He became a full professor in 2013. He had published many research articles about biodiesel synthesis through non-alcohol route. He has strong interest in the area of enzyme kinetics modelling, biocatalysis and reaction process engineering.

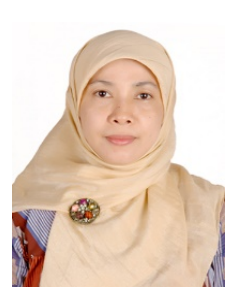

Andi Nuraliyah was born at Soni (Central Sulawesi) on January 20, 1974. She received her bachelor's degree in chemical engineering from Muslim University of Indonesia, Makassar, Indonesia in 1998, the magister engineering in chemical engineering from Gadjah Mada University, Yogyakarta, Indonesia in 2005.

She is now as a Phd student at Universitas research on biocatalysts. Indonesia, Depok, Indonesia. Concentration of 
Photovoltaic Systems and Solar Energy Engineering 
